necrosis of one rectus abdominis, a comparatively small weight of muscle, and from this the patient died of uraemia a few days later. Compartmental muscle necrosis may have a similar outcome. ${ }^{19}$

The most important finding of this work in Newcastle, however, was the very high incidence of death and of uraemia after resuscitation in patients with fractures of the pelvis. Many muscle fibres (as contrasted with muscle tendons) are attached to the pelvis, and traumatic ruptures of muscle bellies produce considerable ischaemic muscle necrosis due mostly to damage to small blood vessels. Erasmus Barlow and I thought that such cases should be given adequate alkaline fluid on admission, both by mouth and by vein.

By early 1945 we were back in London, then under intensive attack by V1 bombs (doodlebugs) and later by V2s, the silent and stealthy big ones, to put into practice the lessons we had learnt in Newcastle. During these later years we recognised also that renal damage associated with abuse of alcohol or barbiturates was due not to specific kidney toxins but to muscle necrosis from the weight of the unconscious body, as it was in carbon monoxide poisoning. Now 86 causes of myoglobinuria with nephropathy as a contingency are recognised.

In the 50 years since these wartime experiences the incidence of traumatic injuries has increased because of mining, industrial, and automobile traffic accidents, even despite enhanced safety precautions, and earthquakes continue to contribute their regular if sporadic challenge, to which we have offered therapeutic guidelines. The use of simple dialysis by Kolff in his general practice in Kampen during the German occupation of The Netherlands revolutionised the treatment of these potentially reversible renal lesions..$^{20}$ The Borst dietary regimen, which spares cell breakdown and potassium release by supplying adequate calories, and our introduction of measures to lower potassium, such as insulin and glucose, have helped. The management of these potentially preventable and reversible cases of anuria after trauma is now well secured by modern dialysis technology (and considerably better than our first struggles with the Kolff machine at Hammersmith in 1946, when only two out of 12 patients survived ${ }^{21}$. The lesson for today is that many of these dialyses for traumatic anuria are avoidable by adequate first aid hydration and alkalinisation as well as by an adequate dietary regimen during recovery.

Finally, tribute should be paid to the Medical Research Council, its scientific workers, and the enthusiastic physicians, surgeons, pathologists, and nurses of the emergency medical service and of the armed forces during the war years - they contributed so much to our knowledge of this subject.

1 Bywaters EGL, Beall D. Crush injuries and renal function. BMJ 1941; 427-32.

2 Bywaters EGL. Ischaemic muscle necrosis. JAMA 1944;124:1103-9.

3 Richards NT, Tattersall J, McCann M, Samson A, Mathias P, Johnson A. Dialysis for acute renal failure due to crush injuries after the Armenian earthquake. BMF 1989;298:443-5.

4 Collins AJ. Kidney dialysis treatment for victims of the Armenian earthquake. Engl f Med 1989:320:1291-2.

5 Knochel JP. Rhabdomyolysis and myoglobinuria. In: Ednoyan S, ed. The kidney in systemic disease. 2nd ed. New York: Wiley, 1981:263-84.

6 Bywaters EGL, Dible JH. The renal lesion in traumatic anuria. Fournal of Pathology and Bacteriology 1942;54:111-20.

7 Baker SL, Dodds EC. Obstruction of the renal tubules during the excretion of haemoglobin. Brf Exp Pathol 1925;6:247.

8 Bywaters EGL, Delory GE, Rimington C, Smiles J. Myohaemoglobin in the urine of air raid casualties with crushing injury. Biochem $\mathcal{f}$ 1941;35:1164-8.

9 Bywaters EGL, Popjak G. Experimental crushing injury. Surg Gynecol Obstet 1942;75:612-27.

10 Bywaters EGL, Stead JK. The production of renal failure following injection of solutions containing myohaemoglobin. $Q \mathcal{f}$ Exp Physiol 1944;33:53-70.

11 Bywaters EGL. Hydronephrosis: histological resemblances to late changes in the crush syndrome kidney. Fournal of Pathology and Bacteriology 1945;57:394-5.

12 Coupal JF. History of the medical department of the US army. Vol 12. Washington, DC: United States Government Printing Office, 1920: 407-577.

13 Bywaters EGL, McMichael J. Crush syndrome. In: Cope Z, ed. Medical history of the second world war. Surgery. London: HMSO, 1953:673-88.

14 Bywaters EGL, Crooke AC, Morris CJOR. Limb compression in the tube shelter disaster. Lancet 1943; ii:373-93.

15 Bywaters EGL, Stead JK. Thrombosis of the femoral artery with myohaemoglobinuria and low serum potassium concentration. Clin $\mathrm{Sc}$ 1945;5:195-204.

16 Bywaters EGL, Dible JH. Acute paralytic myohaemoglobinuria in man. foumal of Pathology and Bacteriology 1943;55:7-15.

17 Grant RT, Reeve EB. Observations on the general effects of injury in man with special reference to wound shock. London: HMSO, 1951. (MRC special report services No 277.)

18 Better OS, Stein JH. Early management of shock and prophylaxis of acute renal failure in traumatic rhabdomyolysis. $N$ Engl f Med 1990;322:825-9.

19 Fleischman $\mathrm{AH}$. Ischaemic necrosis of tibialis anticus muscle with rena involvement. Bulletin of the Hospital for Foint Diseases 1961;22:146.

20 Kolff WJ. First clinical experience with the artificial kidney. Ann Intern Med 1965;62:608-19.

21 Bywaters EGL, Joekes AM. The artificial kidney: its clinical application in the treatment of traumatic anuria. Proceedings of the Royal Society of Medicine 1948;41:420-6.
Departments of Radiology and Surgery, Leicester Royal Infirmary, Leicester LE1 5WW

A C Lamont, FRCR, consultant paediatric radiologist

N J M London, FRCs, lecturer in surgery

Correspondence to: $\mathrm{Dr}$ Lamont.

BrMed f 1990;301:1415-8

\title{
Bell ringers' bruises and broken bones: capers and crises in campanology
}

\author{
A C Lamont, N J M London
}

All you that do intend to ring

You undertake a dangerous thing.

(Change ringers' rules, 1694;

All Saints Church, Stamford)

Abstract

Objective-Todetermine the incidence, aetiology, and outcome of injuries due to bell ringing.

Design-Retrospective review of the last six years' issues of Ringing World, advertisement in Ringing World, and a postal questionnaire sent to 20 active ringing towers.

Subjects-Regular bell ringers.

Results-Seventy nine injuries were identified both from review and by advertisement in Ringing World. The incidence of injury among 221 ringers identified by postal questionnaire was $1 \cdot 8 \%$ a year.

Conclusion-Although sonerous, bell ringing can be dangerous and occasionally even fatal. Doctors should be aware of the dangers to which campanologists expose themselves.

\section{Introduction}

Church bell ringing in the British style is an art peculiar to the English speaking world. It is estimated that there are 40000 bell ringers in England alone and that 3000 towers are rung regularly every Sunday.

Despite the considerable hazards associated with the activity (even the most hardened activists hesitate to call it a sport) little is known about the incidence or range of injuries that occur. As previous medical reports are limited to a single case report ${ }^{1}$ and a humorous but instructive article on coping with crises in campanology ${ }^{2}$ our aim was to investigate the incidence, aetiology, and outcome of campanological trauma. 


\section{Methods}

Injuries due to bell ringing were investigated retrospectively by three methods. Firstly, ringers were invited through advertisements in Ringing World to describe to the authors injuries that they had had or seen. Secondly, the pages of the previous six years of Ringing World were searched for reports of ringing injuries and their treatment. Thirdly, a standardised questionnaire was sent to the captains of twenty randomly selected towers. It requested details of the number of regular ringers in each tower and any injuries that they had had over the previous two years.

\section{Results}

The advertisement in Ringing World and a search of the previous six years' issues produced a total of 79 injuries (table I). Seventeen replies were received from the 20 towers that had been sent questionnaires and showed that a total of 221 regular ringers (representing 442 ringing years) had had or seen eight injuries directly attributable to bell ringing (an annual incidence of $1 \cdot 8 \%$ ). These injuries are detailed in table II. Several associated injuries such as falls from ladders and various pre-existing conditions such as sore wrists and

TABLE I-Details of 79 injuries to bell ringers

\begin{tabular}{|c|c|c|}
\hline Nature of injury & No & Cause \\
\hline Torn fingernails & 1 & Snagged in sally \\
\hline $\begin{array}{l}\text { Degloved finger } \\
\text { Fractures: }\end{array}$ & 1 & Raising bell \\
\hline \multirow[b]{2}{*}{ Finger } & & Broken stay $(n=4)$ \\
\hline & 6 & $\begin{array}{l}\text { Raising bell }(n=1) \\
\text { Caught in coils }(n=1)\end{array}$ \\
\hline Humerus & 1 & Broken stay \\
\hline Femur & 1 & Fell from frame \\
\hline Ribs & 1 & Fell from ladder \\
\hline \multicolumn{3}{|l|}{ Bruises: } \\
\hline Hip & 2 & $\begin{array}{l}\text { Foot trapped in rope }(n=1) \\
\text { Broken stay }(n=1)\end{array}$ \\
\hline Arm & 1 & Caught in neighbour's rope \\
\hline Elbow & 1 & Trapped in rope \\
\hline Hand & 2 & Broken stay $(n=1)$ \\
\hline Corneal abrasion & 1 & Rope flicked in eye \\
\hline Scalping & 1 & Head caught in loop \\
\hline \multicolumn{3}{|l|}{ Rope burns: } \\
\hline Arm & 5 & $\begin{array}{l}\text { Caught in own rope }(n=4) \\
\text { Caught in neighbour's rope }(n=1)\end{array}$ \\
\hline Hands & 5 & Broken stay \\
\hline Tooth extracted & 2 & Rope flicked across mouth \\
\hline \multicolumn{3}{|l|}{ Lacerations: } \\
\hline Nose & 2 & Thumbnail caught nose \\
\hline Scalp & 4 & Falls \\
\hline Near hanging & 4 & Broken stay \\
\hline \multicolumn{3}{|l|}{ Pulled muscles: } \\
\hline Back & 6 & Raising bell \\
\hline Abdomen & 1 & Raising bell \\
\hline \multirow[t]{2}{*}{ Ruptured knee ligament } & 1 & Fall from rope \\
\hline & & $\begin{array}{l}\text { Broken stay }(n=1) \\
\text { Rope caught under foot }(n=1)\end{array}$ \\
\hline \multirow[t]{3}{*}{ Death } & 5 & Hit head on box $(n=1)$ \\
\hline & & Fell into bells $(n=1)$ \\
\hline & & Fell from bell frame $(n=1)$ \\
\hline \multirow{2}{*}{ Suicide } & 2 & Hung in tower $(n=1)$ \\
\hline & 3 & \\
\hline Myocardial infarction & 2 & \\
\hline Arthritis & 8 & \\
\hline Tenosynovitis of wrist & 4 & \\
\hline Tennis elbow & 3 & \\
\hline Ruptures: & & \\
\hline Plantar tendon & 1 & \\
\hline Varicose veins & 1 & \\
\hline Slipped disc & 1 & \\
\hline
\end{tabular}

TABLE II - Details of eight injuries occurring over two years in 17 active ringing towers among 221 regular ringers (an incidence of $1 \cdot 8 \%$ a year)

\begin{tabular}{lc}
\hline Nature of injury & No \\
\hline Pulled abdominal muscles & 1 \\
Rope burns & 3 \\
Wrenched finger & 1 \\
Abraded and bruised hands & 2 \\
Near strangulation & 1
\end{tabular}

cut hands that were exacerbated by ringing were also reported; these were included in table I. Reporting of hand blisters was inconsistent and was therefore ignored.

Four of the eight injuries reported in table II required first aid or medical attention and one was potentially very serious. The figures indicate that although less than $2 \%$ of ringers injure themselves each year, this represents about 724 injuries a year throughout the British Isles and roughly half of these require first aid or other medical attention.

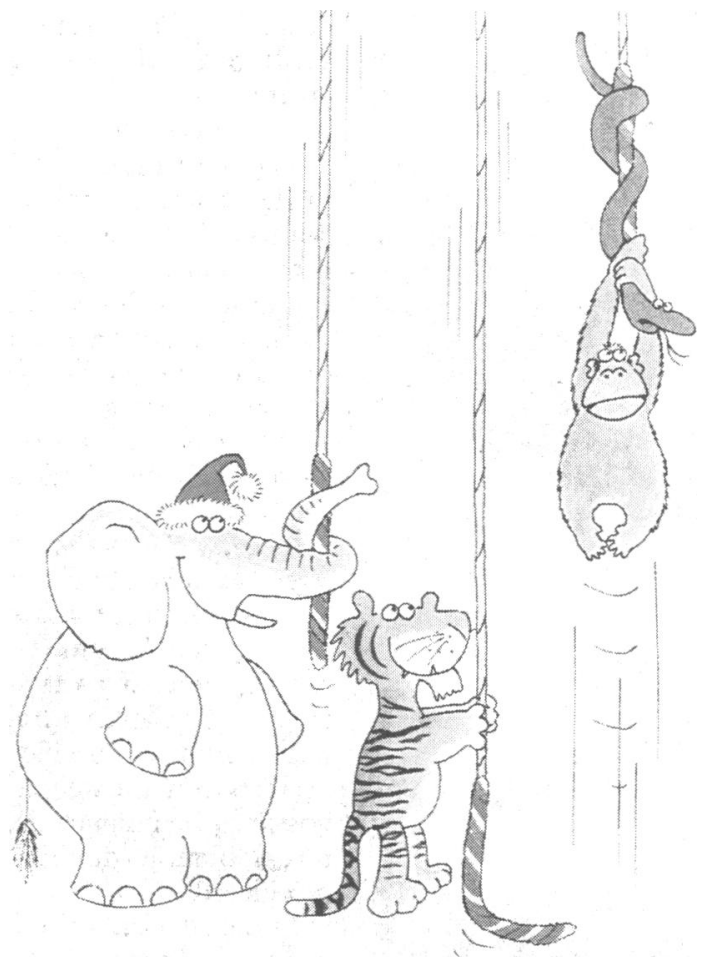

FIG 1-Popular conception of a common hazard of bell ringing - the high speed lift

\section{Discussion}

Medical knowledge of the hazards of bell ringing is limited, and although there is a Guild of Medical Ringers little has been written on the subject. Ringers complain that doctors and physiotherapists, unless they have direct experience of ringing, tend to be unfamiliar with the activity and in particular are ignorant of the weight of the bells. ${ }^{3}$ It is not surprising, therefore, that inappropriate advice is sometimes given.

Many ringers who returned the questionnaires insisted that ringing is very safe, but our results show that this view is rather optimistic. Indeed, this study suggests that many injuries occur as a direct result of ringing.

The types of injuries reported ranged from the banal to the bizarre. Notable by their absence were shoulder dislocations and injuries from articles falling onto ringers, although in one case a ceiling boss came loose and slid down the rope onto the hand, resulting in bruised fingers. (The boss is a metal guide through which the rope passes into the bellchamber.)

Minor rope burns and hand blisters are common among bell ringers, particularly after peal ringing. Both were poorly reported in this series, probably because they are regarded as occupational hazards, and unless severe they are unlikely to be remembered at all. A similar bias may occur with the other injuries reported. People rarely discuss their injuries, except to explain a later incapacity, and minor injuries are quickly forgotten. Similarly, tower captains may feel as a matter of pride that their towers are safer than others and any injuries may be played down. The injuries suffered by bell ringers fall into three broad groups.

\section{INEXPERIENCED RINGERS}

It takes time to learn how to handle a bell rope correctly, how to control a bell (which often weighs considerably more than the ringer), and to acquire the coordination to strike the bell in its proper place at varying speeds and intervals, while avoiding damage to oneself. Learner ringers, like drivers and their teachers, are at greater risk than those who are more experienced. It is novices who commonly experience the most 
notorious hazard of bell ringing - the high speed lift (fig 1). This occurs when the stay (fig 2) breaks, the bell goes over the balance, and the hapless ringer who forgets to release the rope is whisked towards the ceiling at a speed approaching $90 \mathrm{~km}$ per hour.

A typical incident is described in a letter from Australia: "when I caught the sally and allowed the bell to go up to the balance point, with no warning whatsoever the bell weighing about nine hundredweight $(450 \mathrm{~kg})$ went past the balance and I went with it. I could hear voices (not the spiritual kind), telling me to Let go! Let go! and all I could think was I am not going to drop that far onto the cement floor, so I kept going right to the top until my right hand hit the hole and my head hit the ceiling. I had no choice but to let go

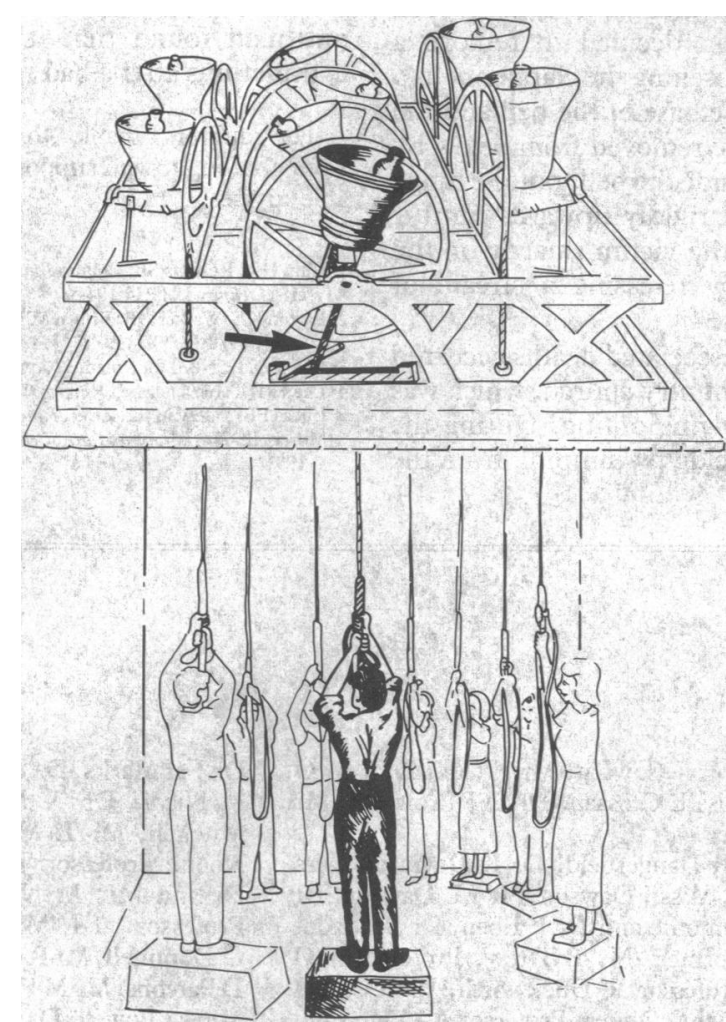

FIG 2-Ringing the changes. Details of pulleys and guides have been omitted. Bells are resting in the raised or inverted position. Wooden stay (arrow) is shown supporting bell at front. When traction on the wheel pulls the bell off balance it falls, rotating freely on its bearings through a full circle. Rope is taken up or given off by the wheel as the bell swings. The ringer controls the speed of ringing either by allowing the bell to pause or by momentarily arresting its flight near the apex of the swing. If a stay breaks, the bell may fall over the balance point, rapidly taking up excess rope. Illustration adapted from Morris ${ }^{\circ}$

at this stage because the rest of me wouldn't fit through the hole. I landed with one foot on the box on which I had been standing - and my right elbow connectedto cause a rather large bruise on my hip. My little finger blew up like a balloon."

This writer was fortunate. A ringer from Kent broke his humerus falling 5 metres from a rope and a woman was concussed and had severe facial injuries when she hit her head on a table in the middle of the ringing chamber. ${ }^{+}$There is also a report of a ringer who was killed when his head struck a beam on the ascent.

The importance of keeping a tight rope was emphasised by replies describing two ringers (both children) who each had a tooth knocked out by the rope flicking across their face. Prompt treatment in each case saved the tooth, and in one instance the tooth was replaced in the socket in the tower.

\section{EXPERIENCED RINGERS}

Most injuries to experiencd ringers seem to occur in moments of inattention; these are "one off," rather

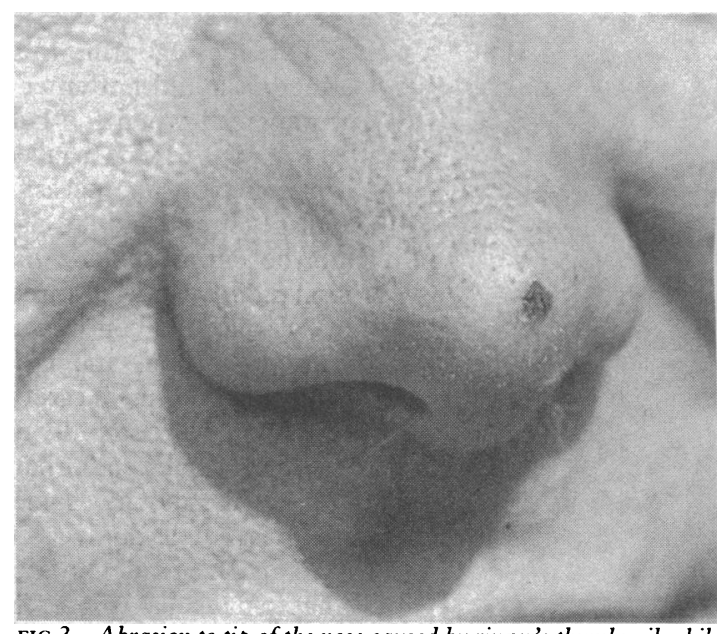

FIG 3-Abrasion to tip of the nose caused by ringer's thumbnail while trying to grasp flapping rope

bizarre injuries. They can occasionally induce marital disharmony. A very experienced and capable ringer caught his left thumb in his nostril as he made to catch the sally; this brought tears to his eyes and resulted in a cut on the end of the nose (fig 3 ) and a comment from his wife to stop picking his nose in public.

An 80 year old ringer was ringing for the harvest service. On the handstroke the rope was checked momentarily in its runners and formed a loop, which fell over his head and tightened just above the eyebrows. As the bell continued its upward swing the rope caused forehead and scalp lacerations. A complete scalping was prevented when he rapidly twisted his head and loosened the rope.

Ringers also suffer from the wear and tear of repetitive movements - tenosynovitis and degenerative arthritis, particularly of the hands, wrists, and thumbs. It is difficult to say whether this is primarily due to ringing or if the activity aggravates a pre-existing condition. At least one medical ringer had to abandon ringing because of an exacerbation of rheumatoid arthritis. As may be expected, inflammatory disease of the elbows and shoulders is also common.

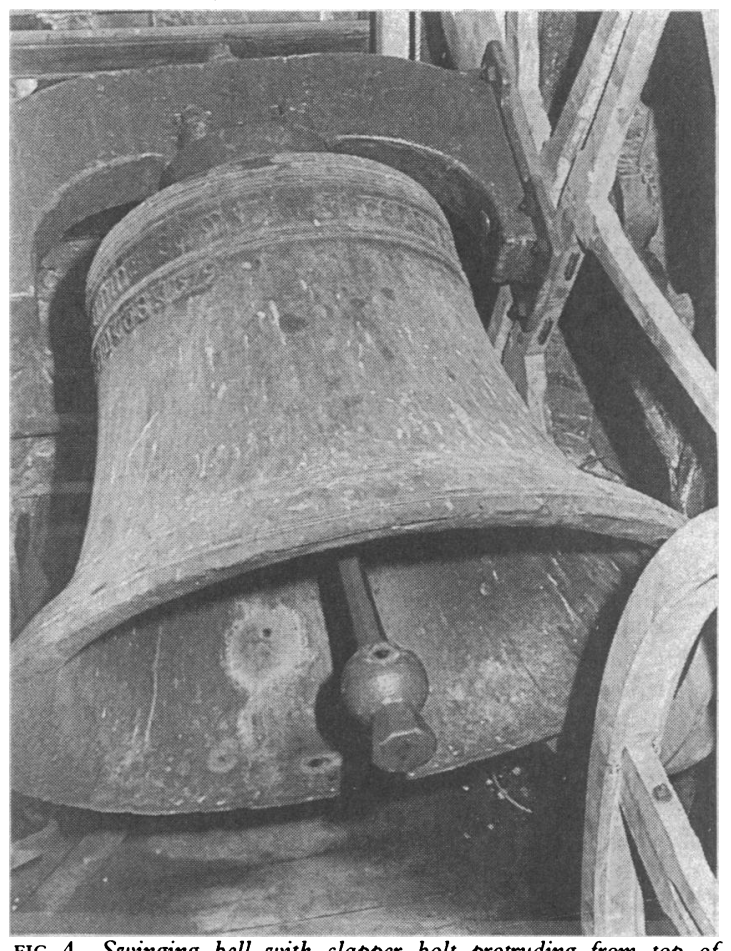

FIG 4-Swinging bell with clapper bolt protruding from top of headstock. This bell weighs $579 \mathrm{~kg}$ (fifth bell, Sutton Bonnington) 


\section{ASSOCIATED HAZARDS}

One message from this catalogue of mishaps is that ringers should not enter into the bell chamber unaccompanied when the bells are up. ${ }^{5}$ A proficient and accomplished ringer failed to tell the band that he was epileptic; on one occasion the tenor was raised in a village church and the clapper went up the wrong way. As he climbed alone into the bellframe he had an epileptic fit and fell directly into the path of the bell. Mercifully the bell was not knocked off the rest as he fell to the floor and he suffered only a minor head injury. The ringers carefully moved him out of harm's way-but were soundly told off by the doctor for doing so. This ringer could have suffered the fate of a vicar who, while showing some choir boys the bells, fell into the raised bells and was crushed to death.

Not all incidents are so dramatic. During bell maintenance a tower captain decided to remove a clapper. This was done by loosening the clapper bolt (a long bolt passing through the base of the bell and the headstock; fig 4). It had to be removed from below by lowering the clapper from inside the bell, but the hinge was stiff and the bolt stuck rigidly upwards until it suddenly released, striking the victim smartly on the crown of the head, thereby releasing a stream of expletives.

The most inexplicable of associated deaths occurred at the high tower of a large country church, which was open to visitors during a ringing outing. During the peal a visitor committed suicide by jumping from the roof of the tower. A ringer commented, "I didn't think our Steadman Caters was that bad."

It is noticeable both from the obituary columns of Ringing World and the questionnaire replies that many people die suddenly immediately after ringing a peal. The reasons for this can only be a source of conjecture. Does the victim have angina during the peal but say nothing for fear of letting the rest of the band down? Perhaps this should be the subject of further research.

Although bell ringing may produce injury it can also be therapeutic. Ten respondents in this study with back pain found relief during ringing. One man with two slipped discs proved on myelography found that the large bells, especially if the sally wasicaught high, gave excellent relief from pain; indeed, the longer the peal the better the relief. Others have used bell ringing as a source of exercise after myocardial infarction, and one man found that it eased his hand and elbow contractures after a bad road traffic accident.

The authors thank John Taylor Ltd, Bellfounders, Loughborough, who supported this research and gave valuable advice.

1 Guly HR, Roberts SB. Collum intertextum - a case report of a campanological crisis. Injury 1982;14:194-5.

2 Easton KE, Walker DR, Brown MBMMcC. Coping with crises in campanolog Injury 1978;14:307-10.

3 Richards R. Need for a medical advisor? Ringing World 1989; No 4093:896.

4 Lee KG. Table a hazard. Ringing World 1984;No 3815:489.

5 Lucas PB. Safety in the tower. Ringing World. 1988; No 4039:906-7.

Morris E. The history and art of change ringing. Chapman and Hall: London, 1931
The cover illustration on this week's issue by Paul Cox shows the banquet in the Banqueting House, Whitehall, on 3 October to celebrate the 150th anniversary of the $B M 7$. The chairman of the journal committee, Dr R A KeableElliott, and the editor of the $B M \mathcal{F}$, Dr S P Lock, were the hosts.

The toast of the $B M \mathcal{F}$ was proposed by Professor Povl Riis, editor of the Danish Medical fournal, and the editor of the BMF responded. The guests were:

Lord Porritt of Wanganui, Lord Walton of Detchant, Sir Donald Acheson, Dame Josephine Barnes, Sir Richard Bayliss, Sir Christopher and Lady Booth, Professor Sir Roy Calne, Sir James Cameron, Sir Cyril Clarke, Sir Richard and Lady Doll, Sir Ian Fraser, Sir Anthony and Lady Grabham, Professor Sir Raymond Hoffenberg, Sir James Howie, Sir David Innes Williams, Sir Robert Kilpatrick, Sir John Peel, Sir George Pinker, Dame Rosemary Rue, Sir John Stallworthy, Professor Sir David Weatherall, Sir Dilwyn Williams.

Dr D Abse, Professor $M$ Adler, Mr T Albert, Dr R Allan, Dr D G Altman, Mr L Altman, Dr M Angell, Miss J Annis, Dr M Ashley Miller, Professor A W Asscher, Dr J G Ball, Professor J E Banatvala, Professor D J P Barker, Mr S M Barnes, Dr J H Baron, Dr P Bartrip, Miss L Beecham, Dr J N Blau, Dr I Bogle, Mrs D Bonn, Mr G Booth, Professor L Bottiger, Mr M Bown, Dr W H Brock, Mr D Browne, Professor N L Browse, Ms S Burkhart, Mr G Burn, Professor J Burnham, Dr W F Bynum, Dr K C Calman, Dr S Carne, Ms K Case, Dr D Chadwick, Dr I Chalmers, Dr D Chamberlain, Professor A Clare, Dr A A Clark, Dr A Comfort, Ms J Connor, Ms M
Cooter, Mr J Cowhig, Mr P Cox, Dr J M O Craig, Miss E Crossan, Dr D J Crowther, Mr E Currer.

Dr P H Dangerfield, Dr K Davidson, Mrs $S$ Davies, Miss J Dawson, Mr J L Dawson, Dr A P Delamothe and Dr F Eben, Dr B Dixon, Mr P Dormer, Ms B Drew, Professor J O Drife, Professor R Duckworth, Professor H Dudley, Dr G Dunea, Professor A J Dunning, Ms C Dyer, Mr D G A Eadie, Mr N Ellis, Mr T A H English, Dr D C Evered, Professor G E Falkowski, Mr J Farrant, Dr and Mrs D J D Farrow, Dr and Mrs I T Field, Mr R Firth, Mr and Mrs R Fishwick, Mr D Fitzgerald, Dr R Fletcher, Dr S Fletcher, Professor F V Flynn, Dr J A Ford, Dr I Forgacs, Dr J M Forsythe, Dr and Mrs R Fox, Mr S Fraser, Mr J Garfield, Mr D Gentleman, Dr R Gillon, Miss D Gloag, Dr F Godlee, Ms C Greenall, Mrs L GreyTurner, Professor V Griffiths, Dr P Groves and Mr N Groves.

Mr J Halliday, Dr O Harlem, Dr J Tudor Hart, Dr D J D Havard, Mrs B Hawkey, Dr C Hawkins, Professor B Haynes, Mr and Mrs R Hayzen, Mr W P Hederman, Miss S Heels, Dr J Heron, Ms R Holland, Professor W Holland, Mr J Holloran, Professor J B L Howell, Professor R A C Hughes, Dr and Mrs E J Huth, Professor M Irving, Mrs R A KeableElliott, Ms L Kelly, Professor A C Kennedy, Professor D N Kerr, Professor R Klein, Dr D Krikler, Professor M J S Langman, Dr and Mrs R A A R Lawrence, Dr J Ledingham, Dr $\mathrm{N}$ Lee, Dr and Mrs J Lee-Potter, Dr and Mrs E B Lewis, Professor W Linford Rees, Mr R Lock, Mrs S P Lock, Mr A Lovell, Professor E J L Lowbury, Mr M Lowe, Dr S Lowry and Dr M Weisz, Mr C Lumsdon, Dr J B Lynch.

Dr A W Macara, Dr and Mrs G Macpherson,
Dr J H Marks, Dr I McKim Thompson, Dr M McNicol, Dr A Mindel, Professor J R A Mitchell, Mr L Moore, Mr G Moss, Mr G Noon, Professor J Norman, Dr S Nundy, Dr and Mrs M Nylenna, Ms M O'Connor, Professor and Mrs B O'Donnell, Dr M O'Donnnell, Mr R Osborne, Mr D Parrott, Mr D Parsons, Mr M Pattison, Professor K Peters, Mr R J Powell, Dr D A Pyke, Dr and Mrs T A Quilliam, Ms D Reece, Dr D A Rees, Dr P J Rees, Dr A S Relman, Dr D Rennie, Professor P Richards, Dr T Richards and Mr C Smallwood, Dr R Richardson, Dr and Mrs A J Riddell, Dr J C Roberts, Dr R F Robertson, Professor Richard Robinson, Professor Roger Robinson, Professor G Rose, Professor M Rosen, Mr A P J Ross, Professor P Rubin, Professor $C$ Rumke, Mrs $S$ Ryan.

Dr $\mathrm{f}$ W Scadding, Mrs M Seward, Ms A Shannon, Mr D Sharp, Mr D Shaw, Professor M Shepherd, Professor A Sims, Dr D A D Slattery, Professor P Sleight, Dr A J Smith and Mrs I Lunde, Mr and Mrs A J Smith, Ms J Smith, Dr and Mrs R Smith, Mr R J H Smith, Dr M Snaith, Dr and Mrs B P Squires, Dr E J Stokes, Dr J F Stokes, Miss M Storey, Dr T D V Swinscow, Professor A Tattersfield, Mrs P Taylor, Mr A Thistlethwaite, Dr L Thomas, Dr and Mrs A K Thould, Dr J S Tobias, Professor $M$ Turner-Warwick, Dr A Vallance-Owen, Dr I Vartiovaara, Mr D Virtue, Dr E Wain, Dr A Walker, Dr and Mrs $M$ Ware, Dr K Warren, Dr P J Watkins, Dr M Weller, Dr F O Wells, Dr W F Whimster, Ms C White, Mr D White, Dr P O Williams, Mr D Williamson, Mrs J Wilson, Dr M A Wilson, Mr A Woodward, Dr P Woolf, and Mr K Young. 